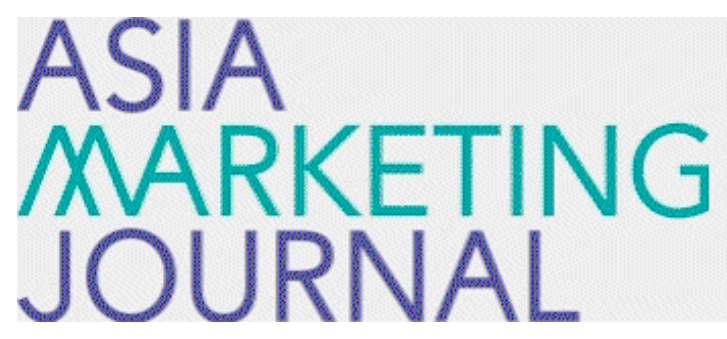

ASIA MARKETING JOURNAL

Volume 5 | Issue 4

Article 3

$12-25-2003$

\title{
Brand Value-Up: 브랜드 진단 및 관리 모형 정립을 위한 시도
}

영뭔 하

성률 전

익태 김

김

성민 홍

Follow this and additional works at: https://amj.kma.re.kr/journal

Part of the Marketing Commons

\section{Recommended Citation}

하, 영원; 전, 성률; 김, 익태; 김; and 홀, 성민 (2003) "Brand Value-Up: 브랜드 진단 및 관리 모형 정립을 위한 시도," Asia Marketing Journal: Vol. 5 : Iss. 4 , Article 3.

Available at: https://doi.org/10.53728/2765-6500.1114

This Article is brought to you for free and open access by Asia Marketing Journal. It has been accepted for inclusion in Asia Marketing Journal by an authorized editor of Asia Marketing Journal. 


\title{
Brand Value-Up: 브랜드 진단 및 관리 모형 정립을 위한 시도*
}

\section{Brand Value-Up: A Diagnostic Tool for Brand Management}

\author{
하영원 (서강대학교 경영학과 교수) \\ ywha@sogang.ac.kr \\ 전성률 (서강대학교 경영확과 교수) \\ syjunesogang.ac. kr \\ 김익태 (제일기획 브랜드 마케팅연구소) \\ ikt ae.kimesamsung.com \\ 김기수(제일기획 브랜드마케팅연구소) \\ keesoo.kim@samsung.com \\ 홍성민(제일기흭 브랜드마케팅연구소) \\ sugameunitel.co.kr
}

\begin{abstract}
본 논문은 기업들의 점증하는 체계적 브랜드 관리에 대한 필요를 인식하면서 이에 부응 하기 위한 하나의 브랜드 관리 시스템을 제안하고자 한다. 일반적으로 전략적인 브랜드 관 리는 브랜드자산의 구축, 브랜드자산의 측정과 진단, 브랜드 자산의 관리를 포함한다 (Keller 1998). 그러나 이 논문에서 제안하고자 하는 브랜드 관리 시스템인 Brand Value$\mathrm{Up}$ 은 주로 상표 자산의 측정과 진단에 관한 시스템이다. 이 논문에서 Brand Value-Up 을 제안하기 위해 우선 기존의 대표적인 브랜드 관리 시스템들을 검토하였다. 그리고 나서 이 들의 미비점들을 분석하였으며, 나아가서 기존 시스템들의 미비점을 보완하는 시스템으로 서 Brand Value-Up 을 소개하였다. 또한 Brand Value-Up 은 고객 중심의 브랜드진단 평가모 델로서 결과지표 (Awareness Power, Functional Power, Image Power)와 성과지표(Brand Performance)로 구분하여 구체적으로 전략적인 시사점을 얻기 위한 모형으로서 제안하였 다. 실제로 주요 국내 브랜드 (21 개 제품 106 개 브랜드)를 대상으로 한 분석을 통해 $\mathrm{Br}$ and Value-Up 의 활용 예를 보였으며, 마지막으로 이 시스템이 갖는 마케팅적인 의미와 시사점을 논의하였다.
\end{abstract}

*논문접수 : 02.02 게재확정 : 03, 12 


\section{1. 서론}

미국 마케팅 협회 (American Marketing Association)의 정의에 의하면 브랜드는 어떤 판 매자 (또는 판매자 집단)의 제품과 서비스의 동일성을 나타내고 경쟁자들의 제품과 서비스 로부터 차별화 하기 위한 이름, 문구, 싸인, 상징, 디자인 또는 이들 중 둘 이상의 결합을 의미한다 (Keller 1998, p.2). 1990 년대에 들어서면서 고조되기 시작한 학계와 실무계의 브랜드에 대한 관심은 최근 들어 더욱 증가하고 있다 (Keller 1998; van Osselaer and Alba 2000; van Osselaer and Janiszewski 2001). 브랜드는 과거에 제품이나 서비스의 동 일성을 확보하기 위한 도구로서의 역할이 강조되었으나 최근에는 점점 더 기업의 중요한 자산으로 인식되는 경향을 보이고 있다 (Aaker 1991). 예컨대 Interbrand 의 추정에 의하 면 2003 년 현재 Coca Cola 의 브랜드 가치는 704.5 억 달러에 달하고 있으며 Microsoft (651.7 억 달러). IBM (517.7 억 달러)이 그 뒤를 잇고 있다. 우리 기업들 중에는 삼성 (108.5 억 달러)이 Sony (131.5 억 달러) 등에 이어 25 위를 차지했다 (Interbrand 2003). Interbrand 의 브랜드 가치 평가에 얼마나 신뢰성과 타당성을 부여 할 수 있는가에 대해 논란이 없는 것은 아니지만, 이 같은 브랜드 가치의 추정액은 무형 자산인 브랜드가 기업 에게 얼마나 중요한가를 일깨워주는 하나의 지표가 되고 있는 것은 사실이다. 기업들이 브 랜드 가치에 대해 부여하는 중요성이 점중함에 따라, 기업들은 자사의 브랜드들을 체계적 으로 관리할 수 있는 도구의 필요성을 절실하게 느끼고 있는 것으로 보인다.

이 논문에서는 기업들의 점증하는 체계적 브랜드 관리에 대한 필요를 인식하면서 이에 부웅하기 위한 하나의 브랜드 관리 시스템을 제안하고자 한다. 일반적으로 전략적인 브랜 드 관리는 브랜드자산의 구축, 브랜드자산의 측정과 진단, 브랜드 자산의 관리를 포함한다 (Keller 1998). 그러나 이 논문에서 제안하고자 하는 브랜드 관리 시스템인 Brand ValueUp 은 주로 상표 자산의 측정과 진단에 관한 시스템이다. 향후 이 시스템은 추가적인 연구 를 거쳐 상표 자산 구축 및 관리에 관해서 더 많은 부분이 보완될 것이다. 이 논문에서 Brand Value-Up 을 제안하기 위해 우선 기존의 대표적인 브랜드 관리 시스템들을 점토하였 다. 그리고 나서 이들의 미비점들을 분석하였으며, 나아가서 기존 시스템들의 미비점올 보 완하는 시스템으로서 Brand Value-Up 을 소개하였다. 또한 주요 국내 브랜드를 대상으로 한 실중 분석올 통해 Brand Value-Up 의 활용 예를 보였으며, 마지막으로 이 시스템이 갖 는 마케팅적인 의미와 시사점을 논의하였다.

\section{2. 기존 브랜드 모델의 고찰}

기존 브랜드 자산에 대한 정의는 세 가지로 나뉘어진다. 첫째, 재무적 관점으로 이 관점 에서는 브랜드 자산을 브랜드를 붙이지 않은 제품의 판매로 인한 현금 흐름보다 브랜드를 붙인 제품의 판매로 인한 현금흐름이 더 증가하여 발생하는 현금 흐름 중분 (incremental cash flow)의 순현가로 보고있다 (Simon and Sullivan 1993). 둘째, 마케팅적 관점으로 고 객이 어떤 브랜드에 대하여 호감올 갖게 됨으로써 그 브랜드를 붙이고 있는 제품의 가치가 증가된 부분으로, 브랜드 자산을 제품이나 서비스가 기업이나 그 기업이 고객에게 제공한 
가치에 추가되거나 감소된 브랜드, 브랜드명, 심벌 둥과 연결된 일련의 자산과 부채로 본 다 (Farquhar 1989; Aaker 1991). 셋째, 고객에 근거한 브랜드자산 (customer-based brand equity)으로 브랜드 자산을 그 브랜드에 관한 지식 (brand knowledge)이 그 브랜드의 마케 팅에 대한 고객의 반웅에 미치는 차별적 효과 (differential effects)로 보는 시각이다 (Keller 1993). 이같이 세가지 관점에서 내려진 브랜드 자산에 대한 정의는 학계와 실무계 에서 브랜드 자산을 측정하기 위한 다양한 시도로 이어졌다. 그리고 어떤 요소들이 브랜드 자산을 구성하는가에 대한 견해의 차이와 측정방법의 차이에 의해 학계와 실무계에서 제안 된 모델들은 다양한 형태를 보여주고 있다.

우선, 브랜드 자산 형성 원천에 관한 모델로 마케팅 학자들이 제안한 것으로는 Aaker (1996)의 Brand Equity Ten 과 Keller (1993)의 Brand Knowledge 를 중심으로 하는 모델을 대표적인 예로 들 수 있다. 브랜드자산을 형성하는 원천으로 Aaker (1996)는 브랜드로열티, 지각된 품질, 연상, 인지도 둥의 10 가지를 제시하고 있다. Keller (1993)는 브랜드자산을 소비자들이 브랜드에 대하여 가지고 있는 브랜드 지식의 형태로 파악하였고, 브랜드에 관 한 지식을 다시 세부적으로 브랜드 인지와 브랜드 이미지로 구분하였다. 이 두 가지 모델 은 브랜드 자산을 측정하기 위한 항목을 체계화하였다는 점에서 의의가 있으며, Aaker 의 모델은 인지도, 연상 등의 직접적인 소비자 관련 변수들 이외에도 시장 변수 (시장가격, 유통 커버리지 둥)를 고려하고 있다는 점이 그 특징이라고 할 수 있으며, Keller 모델은 브랜드 이미지의 차원을 소비자가 갖고 있는 브랜드 관련 연상들의 호의도 (favorability), 강도 (strength), 특이성 (uniqueness)으로 보고있다는 점이 그 특징이다.

브랜드 자산 형성 원천에 관한 모델을 실무적으로 적용한 예로는 Young \& Rubicam 의 Brand Asset Valuator 와 덴츠의 D-Breed 가 대표적이다. Young \& Rubicam 모델은 브랜드의 4 개 기본 지표로 차별성 (differentiation), 적절성 (relevance), 높은 평가 (esteem), 지식(knowledge)을 상정하고 브랜드의 강도 (차별성 $\times$ 적절성)와 브랜드의 지위 (높은 평 가 $\times$ 지식)를 두 축으로 하여 'Power Grid' 를 작성하고 브랜드 진화의 관점에서 브랜 드 자산을 측정하고 관리하는 방법을 제시하고 있다 (Aaker 1996). 그리고 덴츠의 D-Breed 는 브랜드 인지, 이미지 연상, 지각품질 둥 6 가지 브랜드지표를 이용한 경로분석과 군집 분석을 통해 소비자의 마음 속에서 브랜드에 대한 평가가 구축되는 과정을 정교화 가능성 모델 (ELM: Elaboration Likelihood Model)의 시각에서 분석하고 있다.

브랜드 자산 형성의 원천에 관한 모델들과는 달리 브랜드 자산으로 인한 시장에서의 성 과에 주된 관심을 갖는 일군의 모델들이 있다. 이 모델들은 브랜드 자산이 실제 시장에서 어떤 성과를 보여주고 있는지를 구체적으로 측정하는데 중점을 두고 있으며, 주로 재무희 계적 또는 마케텅적 관점에서 브랜드자산을 평가하는 방법이다. 예컨대, 브랜드의 자산을 주식가치를 이용하여 측정하는 모형 (Simon and Sullivan 1993)과 선호의 잔차 (residual) 를 이용한 분석 방법 (Kamakura and Russell 1993) 등이 이에 속한다. 주식가치를 이용한 방법은 어떤 기업의 주식가격이 그 기업이 미래에 힉득할 현금 흐름의 현재가치를 반영한 다는 가정하에 재무제표상 유형자산의 합에서 산출된 재무적 시장가치와 무형자산을 구성 하는 요소 중 브랜드와 관련 없는 요소들 (특허권, R\&D 능력 등)의 가치를 주가 총액에서 차감하는 방법으로 브랜드자산을 측정하는 방법이다 (Simon and Sullivan 1993).

잔차적 분석 방법은 브랜드자산을 전반적 선호 (overall preferences)에서 객관적으로 측정하여 얻을 수 있는 물리적 제품속성에 대한 다속성 선호를 차감하여 얻게 된다. 이러 한 잔차 분석 방법으로 Kamakura and Russell (1993)은 단일 원천의 스캐너 데이터 
(single source scanner data)를 이용한 브랜드자산 평가방법을 제안했는데, 구매시 브랜 드에 의한 영향이 어느 정도인지를 파악하여 브랜드자산을 측정하고 있다. 다른 잔차 분석 방법으로 Conjoint 분석을 이용한 측정법은 브랜드 자산을 의사소통 방법을 통해 소비자들 로부터 직접 측정한다는 데 그 특징이 있다고 하겠는데, Park and Srinivasan (1994)은 Conjoint 분석의 한 유형인 Self-explicated conjoint 분석울 활용하여 브랜드 자산을 측 정하는 방법을 제안하였다.

브랜드 자산 시장 성과 모델은 실무계에서도 활발하게 개발되어 활용되고 있다. 예컨대 Interbrand 에서는 단계별 브랜드 가치 산출방식올 개발하여 영업이익을 산출하고 브랜드 의 역할(role of branding)과 브랩드강도(brand strength)를 자체적으로 산정하여 여러 브 랜드들의 가치를 종합적으로 평가하고 있다. 이 모델은 최초로 브랜드 가치를 금액화한 시 도로서 실무계에서 나름대로의 위상을 확보하고 있다. 국내에서는 산업정책 연구원 둥에서 Interbrand 와 유사한 방법으로 브랜드 가치를 평가하려는 시도가 진행 되었다 (산업정책 연구원 2003). 그리고 중앙리서치에서는 K-BEEM 이라고 하여 브랜드가 붙어있지 않은 가상 의 제품과 브랜드가 붙어 있는 제품을 비교하여 1 년 동안 힉득할 수 있는 순수한 부가가 치로 브랜드 가치를 측정한 바 있다 (안광호. 한상만, 전성률 2003).

위에서 소개한 기존 모델들은 각 모델이 가지고 있는 특장점에도 불구하고 여러 가지 면 에서 한계를 지니고 있다. 브랜드 자산형성 원천모델은 성과변수의 측징방법이 모호하고 브랜드 자산 구성 요소간의 연결관계 또는 인과관계가 모호하다 (Keller 1993). 따라서 브 랜드 자산의 구성요소에 대해 개넘적으로는 비교적 잘 정리되어 있다는 장점이 있으나 실 천적 방법론의 제시라는 면이 부족하기 때문에 현실에 적용하기가 어려운 경우가 많다. 한편 브랜드 자산 시장 성과 모델은 결과물로 전체적인 브랜드 가치만을 제시하고 있는 경 우가 많아 브랜드 가치를 제고하기 위한 전략적 방법론을 도출해내기가 어렵다. 또한 이 모델들의 경우 결과적인 지수로서 브랜드 가치를 가능한 한 금액으로 측정하는데 역점올 두기 때문에 브랜드 가치률 측정하기 위한 조작적 개념의 타당성이 문제시 되는 경우가 종 종 있다 (Park and Srinivasan 1994, p.281).

본 연구에서 제시하는 Brand Value-Up 은 위에서 살펴본 기존 모델들의 한계점들을 가능 한 한 많이 보완하기 위한 브랜드의 진단 및 측정모형으로 개발되었다. Brand Value-Up 은 고객에 근거한 브랜드 자산의 관점에서 브랜드를 진단하고 측정하는 방법을 따르고 있다.

\section{3. 브랜드자산 진단모델 (Brand Value-Up 모델)}

\section{1 브랜드자산 진단모델 개발 방향}

Brand Value-Up 모델에서 브랜드자산은 고객(소비자)관점에서 "브랜드가 고객의 반응에 미치는 차별적 효과” 로 정의한다 (Keller 1993). 그러므로 Brand Value-Up 모델은 무(無) 브랜드와 브랜드가 있는 상태에서의 비교가 아닌 총체적 (holistic) 관점에서 브랜드 자산 올 설명하고 있어, 브랜드진단을 통해 구체적인 전략올 수립할 수 있는 실용적 모델이라고 할 수 있다.

Brand Value-Up 모델은 기존 학자들의 연구결과를 발전시켜 (Farquhar 1989; Aaker 1991; 
Keller 1993), 브랜드자산의 형성원천과 시장성과를 구분하고자 한다. 브랜드자산 형성 원 천으로는 인지 (awareness), 지각품질 (perceived quality), 이미지/연상 (image/association)이 포함되며 시장성과로는 브랜드 자산의 형성원천에 의해 결과적으로 나타나는 지표 로 브랬드 로열티, 구매의향 둥이 포함된다.

이렇게 브랜드자산의 형성원천과 시장성과를 나눈 후 두 지표간에 인과관계를 분석하여 전략적 제언을 도출할 수 있는 모델을 개발하고자 하는 것이 Brand Value-Up 모델의 중요 한 기본 개발방향이라고 할 수 있다.

\section{$3.2 \mathrm{Br}$ and Value-Up 모델의 구조}

$\mathrm{Br}$ and Value-Up 모델은 크게 성과지표와 결정지표로 구성되어 있는데, 성과지표는 $\mathrm{Brand}$ Performance 로, 성과지표를 결정하는 결정지표로는 Awareness Power, Functional Power, Image Power 로 구성되어 있다.

<그림 1> Brand Value-Up 모델 구조

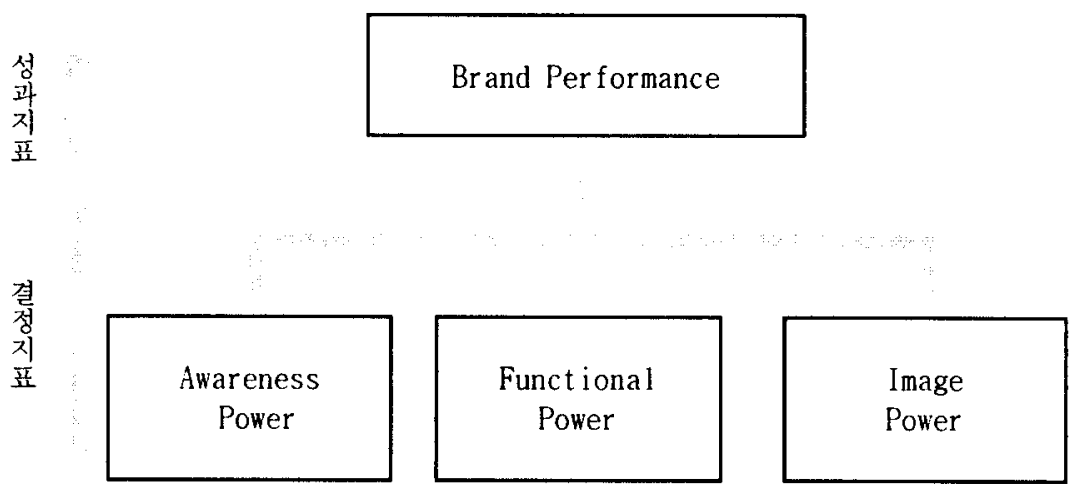

\subsubsection{Brand Performance(성과지표)}

Brand Performance 는 브랜드자산의 성과지표로 브랜드로열티, 상대적지각가치, 구매의 향 이라는 세 부분으로 구성되어 있다. 특히, 타 모델에서 브랜드로열티 동의 측정항목이 강력한 브랜드자산이 구축되어 결과적으로 나타나는 성과지표로 보지 않고, 다른 영향요인 과 동일하게 취급되고 있지만 Brand Value-Up 모델에서는 고객의 브랜드에 대한 충성도를 보여주는 브랬드로열티 등은 성과지표를 결정하는 중요한 구성요소로 간주된다.

브랜드로열티는 인지적 접근과 행동적 접근의 정의가 있다. 인지적 접근에 따른 정의에 의하면 브랬드로열티는 “고객이 가지는 특정 브랜드에 대한 애착의 정도" (Aaker 1991)를 말하며, 행동적 접근으로는 “여러 브랜드 대안들 중에서 하나 또는 그 이상의 브랜드에 대 한 지속적인 편향된 구매행동” (Jacoby \& Chestnut 1978)을 말한다.

이학식, 안광호, 하영원 (2001)은 “한 브랜드에 대한 높은 반복구매 정도와 구매된 브랜 드에 대한 호의적인 태도" 라고 정의함으로써, 인지적 접근과 행동적 접근을 모두 반영하 
여 설명하고 있기도 하다. Brand Value-Up 모델에서는 최종적인 브랜드에 대한 에착 정도 를 성과지표에 포함시키기 위해 브랜드로열티는 행동적 접근에 의해 한 브랜드의 연속적인 구매횟수나 전환 정도를 지수화하여 측정하고 있다.

소비자가 상표선택을 할 때 과거 구매가 현재 구매에 미치는 영향은 이전 구매에서 A 라 는 브랜드를 선택하였다면 이후에도 계속 $\mathrm{A}$ 브랜드를 선택할 수 있고, 이전 구매에서 A 라 는 브랜드를 선택하고 이후에 다른 B 브랜드를 선택하는 두 가지 형태로 나타날 수 있다 (Kahn, Kalwani, and Morrison 1986). Papat la and Krishnamurthi (1992)의 연구에서 동일 한 상표를 선택하는 소비자를 “상표충성자”, 다른 상표를 선택하는 소비자를 “상포전환 자" 라고 하였는데, Brand Value-lp 모델에서도 동일하게 소비자의 [이전, 현재, 향후] 브 랜드 선택형태를 통해 Brand Loyalty를 지수화하고 있다.

상대적 지각가치 (relative perceived value)는 선도제품 (flagship product)을 기준으 로 각 제품에 대해 느끼는 가치를 가격으로 표현한 것이며, 경쟁사대비 차이로 측정하게 된다. 가격과 경쟁구도가 함께 반영되어 경쟁제품 대비 대상제품에 대한 가치를 상대적으 로 지수화하게 된다.

가격 프리니엄 (price premium)이 “브랜드가 제시되었을 때 추가적으로 지불할 수 있는 가격" (Aaker 1991)이지만 상대적 지각가치는 고객이 생각하는 브랜드에 대한 지각가치를 100 점 단위로 지수화하기 위해 개넘화 되었으며, 조사 비교 브랜드중 고객이 생각하는 최 고 브랜드률 100 으로 평가하였을 경우. 다른 브랜드에 대한 상대적 점수를 부여하는 방법 으로 측정한다.

구매의향은 제품군내에서 어떤 특정 상품올 구매할 의향으로 실제 "구매할 의향이 있느 냐?" 라는 질문에 7 점 척도로 답하도록 되어 있다. 이러한 척도는 이미 MacKenzie, Lutz, and Belch (1986). Machleit and Wilson (1986)둥 많은 학자들에 의해 사용되어진 바 있다.

\subsubsection{Awareness Power}

dwareness Power 는 "소비자 마음 속의 특정 브랜드 존재의 강도" (Aaker 1991)라고 할 수도 있으며, "어떤 조건 하에서 특정 브랜드를 식별할 수 있는 소비자의 능력" (Keller 1993)이라 할 수 있다. 브랜드인지도는 상기 (recall)와 재인 (recognition)으로 구성되어 있으며 (Hutchinson, Raman and Mantrala 1994), 본 모델의 Awareness Power 는 한 제품 범주내에서 브랜드의 가장 먼저 떠오르는 정도를 나타내는 대표성지수 (top of mind), 구 매시점에서 구매선택의 고려가능군(保)에 포함되는 정도를 나타내는 고려가능지수 (top3), 그리고 비보조상기 (unaided recall), 보조상기 (aided recall)를 통합하여 지수화하였다.

본 모델에서는 Awareness Power 는 “고려 상품군의 구성 즉, 어떤 브랜드가 고려 상품 군에 포함되는가의 문제는 당시의 브랜드현저성 (brand salience)에 의해 좌우된다 (Nedungadi 1990)" 는 점을 강조하고 있는 데. 어떤 도움없이 최초로 브랜드률 상기하는 정도인 최초상기도가 그만큼 중요한 비중을 차지하고 있다 (Axelrod 1968, 1986; Miller and Berry 1998).

\subsubsection{Functional Power}

Functional Power 는 "소비자가 특정 브랜드에 대해 지각하는 품질·성능-속성·가치 등의 우수성이나 우월성" 율 말하며, 지각품질 (perceived quality)의 개녑을 보다 발전시 켜 개념화하였다. Zeithaml (1988)은 지각품질을 "제품의 전반적인 우수성이나 우월성에 
대한 소비자의 판단" 이라고 하였으며, 브랜드에 대한 눈에 보이지 않는 전반적인 감정으 로서 브랜드와 깊게 관련된 신뢰감과 성능 둥 제품의 특성을 포함한 내면적 차원에 기초한 개념이라고 할 수 있다.

기존의 연구 (Kamakura and Russel 1993; Park and Srinivasan 1994)에서는 속성에 기초 한 브랜드자산은 주관적으로 지각한 품질에서 객관적으로 평가한 품질을 차감한 부분이라 고 강조하기도 하였지만, 브랜드의 품질에 대한 소비자 인식은 브랜드자산을 형성하는데 매우 중요한 영향을 끼친다. 따라서 지각품질은 브랜드자산의 구성항목으로 중요하게 인식 되고 있는 것이다 (Aaker 1991).

Brand Value-Up 모델에서는 각 제품군에 맞는 지각품질 항목을 상황에 맞게 (situationspecific) 조정할 수 있는 Fishbein 모델 (1975)을 적용하여 브랜드자산에 지각 품질이 포 함되어 측정될 수 있도록 하였다. 이를 Functional Power 라고 하여 브랜드가 지니고 있는 품질 속성에 대한 소비자 인식의 차이를 측정하기 위해 호의성 (favorability), 강도 (strength), 톡이성 (uniqueness) 개념을 사용하였다. Keller (1993)는 브랜드 지식의 구 조에서 브랜드 연상의 형태를 속성, 편익, 태도로 구분하면서, 이런 연상은 호의성, 강도, 특이성에 따라서 달라진다고 하였다. Brand Value-Up 모델에서는 브랜드의 속성을 Functional Power 로 구분하고 기능적인 속성의 차이를 측정하기 위해 Keller (1993)가 강 조한 호의성, 강도, 특이성을 개념을 활옹하여 지수화 (100 점 만점) 하고자 하였다. Keller (1993)가 개념화한 호의성, 강도, 특이성을 Brand Value-Up 모델에서는 좀더 확장 시켜 각 개념에 대한 측정뿐만 아니라 이를 다음과 같은 Functional Power 계산식을 통해 지수화하여 브랜드간의 차이를 쉽게 파악할 수 있도록 하였다.

호의성은 브랜드연상에 대한 평가라고 한다면, 강도는 연상에 대한 신념 (belief)의 정 도라고 할 수 있고 특이성 (uniqueness)은 경쟁관계를 고려할 때 어떤 특성에 대하여 다른 브랜드와 공유하지 않는 정도를 말한다 (Keller 1993). 따라서 Functional Power 에서는 속성에 대한 평가와 신념을 구조적으로 측정하도록 도와주는 Fishbein 모형 (Ajen and Fishbein 1980)을 기본적으로 적용하여 보완하였다. 또한 Functional Power 에서는 각 품 질 속성에 대하여 중요도를 평가한 후에 각 브랜드에 대한 평가를 실시하게 되는데, 품질 속성에 대한 브랜드간 평가 (1 점-7 점) 차이를 강도로 보았다. 브랜드간 평가 차이 (강도) 에서 특이성을 측정하기 위해 $\mathrm{A}$ 브랜드에 대한 평가에서 다른 경쟁 브랜드 평가의 평균을 차감하는 방법을 사용하였다. Keller (1993)는 특이성을 측정하기 위해 얼마나 특이한지 (unique) 직접적으로 질문하는 방법과 브랜드연상의 특성을 경쟁 브랜드와 비교하는 간접 적인 방법 두가지를 제시하고 있는 데, Brand Value-Up 에서는 후자의 방법에 가깝게 측정 을 시도한 것이다. 장점이라면 특이성을 경쟁 브랜드간 비교하면서도 각 품질 속성에 대한 브랜드 평가 (강도)를 실시한 후 이를 활용하여 평가 대상 브랜드(A)와 다른 경쟁 브랜드 평가의 평균의 차이로 측정하여 강도와 특이성을 함께 계산한다는 점이다. 강도와 특이성 은 상이한 개념을 측정하여 지수화에 포함되기 때문에 합의 방식을 사용하였다.

$$
F P_{i j}=\sum_{p=1}^{n}\left[\frac{I_{i p}}{\sum_{p=1}^{n} I_{i p}} \times\left(S_{i j p}+U_{i j p}\right)\right]
$$




$$
U_{i j p}=S_{i j p}-\frac{\sum_{k=1}^{m-1} S_{i k p}}{m-1} \quad(\text { 단, } k \neq j)
$$

$\mathrm{FP}_{i j}$ : 소비자 $\mathrm{i}$ 의 브랜드 $\mathrm{j}$ 에 대한 Functional Power

$I$ ip : 소비자 $\mathrm{i}$ 의 속성 $\mathrm{p}$ 에 대한 중요성 (importance) 평가

$\mathrm{S}_{i j p}$ : 소비자 $\mathrm{i}$ 의 브랜드 $\mathrm{j}$ 에 대해서 가지고 있는 속성 $\mathrm{p}$ 에 대한 강도(strength) 평가

$\mathrm{U}_{i j p}$ : 소비자 $\mathrm{i}$ 의 브랜드 $\mathrm{j}$ 에 대해서 가지고 있는 속섬 $\mathrm{p}$ 에 대한 특이성(uniqueness) 평가

$n$ : 전체 속성의 수

$m$ : 전체 브랜드의 수

\subsubsection{Image Power}

Image Power 는 "소비자가 특정 브랜드에 대해 일으키는 연상과 연상들이 결합되어 형 성된 브랜드에 대한 전체적인 인상” 을 말한다. 즉, 브랜드이미지란, 브랜드에 대해서 소 비자가 가지고 있는 일련의 신넘 (Kotler 2003)이나 소비자들의 기억 속에 자리잡고 있는 전체적인 연상들의 집합 (Aaker 1991)이라 할 수 있다. 브랜드이미지는 제품속성 (product attributes), 소비자 편익 (consumer benefits), 보랜드개성 (brand personality) 등으로 구성되어 있지만 (Plummer 1985; Keller 1993), Brand Value-Up 모델에서는 졔품과 관련된 품질 속성은 Functional Power 에서 측정하기 때문에 상징적 이미지를 나타내는 Image Power 는 세부적으로 Personal Image Power 와 Social Image Power 로 나뉘어 측정된다.

Fournier (1998)는 소비자-브랜드 관계를 구성하는 요소로 사랑과 열정 (love/ passion), 자아 관련성 (self-connection), 몰입 (commitment), 친밀감 (intimacy), 상호 의존성 (inter-dependence), 동반자의식 (brand partner quality)의 6 가지를 제시하였다. 브랜드 와 소비자의 관계는 상징적인 상호주의 측면에서 이해될 수 있는데 (Solomon 1983), 브랜 드를 인간의 톡성과 관련지어 생각하는 브랜드의 내적 관련성도 중요하지만 개인간 관계 (interpersonal relationship), 즉 사회적 환경 속에서의 이미지의 상징적인 상호 전달도 중요하게 인식되어 왔다 (Nicosia and Mayer 1976; Solomon 1983; Fournier 1998). 제품이 나 브랜드를 구매할 때 소비자는 사회적인 환경 속에서 기대되는 역할올 인지하고 이에 따 라 어떤 행동을 할 때 제품이나 브랜드의 상징적인 측면이 큰 영향을 끼치는 것이라고 할 수 있다 (Solomon 1983, p.325).

Brand Value-Up 모델의 Image Power 에서 Personal Image Power 는 "특정 브랜드에서 나 타나는 인간적 특성 또는 기질" 이다. 기본적으로 브랜드개성을 말하지만 $\mathrm{Br}$ and Value-Ulp 모델에서는 단지 한 브랜드를 인간으로 표현하였을 때 그 브랜드와 관련된 인간적인 특성 (Aaker 1997)을 측정함과 동시에 소비자 자신 또는 자신이 바라는 이미지와의 충족도 (Intra Personal Fit)를 측정한다는 점이 차이가 있다.

Social Image Power 는 "특정 브랜드가 타인에게 비춰지는 특성 또는 소비자 사이에서 인식되는 이미지” 를 말한다. Brand Value-Up 모델의 Social Image Power 는 사회적으로 소비자와 브랜드간의 관계가 어느정도 일치하는지의 정도 (Inter Personal Fit)를 측정하 여 지수화하게 된다. 특히 개인이 바랍직하다고 기대하는 그릅, 그리고 그 안에서의 역할 
과 이미지를 측정하게 되는데, 주위 수용, 주위선호, 선망대상의 사용가능성, 관심/ 화제 성 둥을 측정하게 된다 (cf. Park, Jaworski, and MacInnis 1986, p.136).

Image Power 도 Functional Power 와 비숫하게 호의성, 강도, 특이성 개념을 활용하여 Personal Image Power 와 Social Image Power 를 각각 다음과 같이 종합적으로 지수화한다. Image Power 에서는 Functional Power 의 계산식과 유사하나 품질 속성에 대한 중요도 평가 대신, 이미지 항목에 대한 브랬드와 나 (개인)과의 이미지 일치도 (fit)를 측정하여 가중 치를 부여하는 방식으로 지수화에 포함하였다. 또한 Functional Power 에서와 마찬가지로 브랜드간 평가 차이 (강도)에서 특이성을 측정하기 위해 $\mathrm{A}$ 브랜드에 대한 평가에서 다른 경쟁 브랜드 평가의 평균을 차감하는 방법을 사용하였다.

$$
\begin{gathered}
I P_{i j}=\sum_{p=1}^{n} I \frac{F_{i p}}{\sum_{p=1}^{n} F_{i p}} \times\left(S_{i j p}+U_{i j p}\right) J \\
U_{i j p}=S_{i j p}-\frac{\sum_{k=1}^{m-1} S_{i k p}}{m-1} \quad(\text { 단, } k \neq j)
\end{gathered}
$$

$\mathrm{IP}_{i j}$ : 소비자 $\mathrm{i}$ 의 브랜드 $\mathrm{j}$ 에 대한 Image Power

$\mathrm{F}_{i p}$ : 소비자 $\mathrm{i}$ 의 속성 $\mathrm{p}$ 에 대한 이미지 일치도 (fit) 평가

$\mathrm{S}_{i j p}$ : 소비자 $\mathrm{i}$ 의 브랜드 $\mathrm{j}$ 에 대해서 가지고 있는 속성 $\mathrm{p}$ 에 대한 강도 (strength) 평가

$U_{i j p}$ : 소비자 $\mathrm{i}$ 의 브랜드 $\mathrm{j}$ 에 대해서 가지고 있는 속성 $\mathrm{p}$ 에 대한 특이성 (uniqueness) 평가

$n$ : 전체 속성의 수

$m$ : 전체 브랜드의 수

\subsubsection{Brand Value-Up 모형 적용예}

$\mathrm{Br}$ and Value-Up 모델의 모형은 <그림 1>와 같이 Brand Performance 를 결정하는 데 있어 서 Awareness Power, Functional Power, Image Power 가 영향을 주며 회귀분석을 실행한 결과 높은 모형적합성을 보였다. 실제 국내 시장 적용을 위한 조사에서 대표적으로 휘발유 브랜드를 선택하여 분석한 결과에서 (<표 1> 참조) 본 모형은 통계적으로 유의하게 나타났 으며 $(\mathrm{F}(3,1496=557.395, p<.001) \mathrm{R}$ 제곱이 .528 로 비교적 높은 설명력을 보여 주었다. 휘 발유에서 Brand Performance 의 회거식은, Brand Performance $=-23.798+.236$ Awareness Power +.493 Functional Power +.741 Image Power 로 나타났다. 이때 본 회귀모형에서도 오차항 $(\varepsilon)$ 에 대한 기본가정을 충족시켜 주어야 하는데, 더빈-왓슨(Durbin-Watson) 통계량 이 1.926 으로 2 에 가까워 인접한 오차항들은 독립성을 만족하고 있으며 잔차도 정규분포 에 가까워 정규성을 만족하고 있다.

본 모형에서 가장 중요하게 고려될 부분이 다중공선성 문제인데, <표 1>에서도 볼 수 있듯 이 공선성 통계량인 공차한계와 분산팽창요인(VIF)이 다중공선성을 심각하게 간주할 겅도 
는 아닌 것으로 나타났다.

<표 1> Brand Performance 회거 분석 (휘발유)

\begin{tabular}{|c|c|c|c|c|c|c|c|c|c|}
\hline \multirow{2}{*}{ 종속변수 } & \multirow{2}{*}{ 독립변수 } & \multicolumn{4}{|c|}{ 상관관 계 } & \multirow{2}{*}{$\mathrm{R}$ 제곱 } & \multirow{2}{*}{$\mathrm{F}$ 값 } & \multirow{2}{*}{$\begin{array}{l}\text { 유의확룰 } \\
\mathrm{F} \text { 변화량 }\end{array}$} & \multirow{2}{*}{ B } \\
\hline & & $Y$ & $\mathrm{X} 1$ & $\times 2$ & $x_{3}$ & & & & \\
\hline $\mathrm{BP}$ & $\begin{array}{l}\text { 상수 } \\
\mathrm{AP}(\mathrm{X} 1) \\
\mathrm{FP}(\mathrm{X} 2) \\
\mathrm{IP}(\mathrm{X} 3)\end{array}$ & $\begin{array}{l}1.000 \\
.625 \\
.601 \\
.647\end{array}$ & $\begin{array}{r}1.000 \\
.523 \\
.574\end{array}$ & $\begin{array}{l}1.000 \\
.768\end{array}$ & 1.000 & .528 & 557.395 & .000 & $\begin{array}{l}-23.798 \\
.236 \\
.493 \\
.741\end{array}$ \\
\hline
\end{tabular}

\begin{tabular}{|l|c|c|}
\hline \multirow{2}{*}{ 더빈-왓슨 } & \multicolumn{2}{|c|}{ 공선성통계량 } \\
\cline { 2 - 3 } & 공차한계 & VIF \\
\hline \multirow{4}{*}{1.926} & & \\
& & \\
& .654 & 1.529 \\
& .400 & 2.301 \\
& .369 & 2.711 \\
\hline
\end{tabular}

* AP: Awareness Power, FP: Functional Power, IP: Image Power

\subsubsection{Brand Value-Up 모델의 의의}

본 연구에서 제시한 Brand Value-Up 모델의 구조를 통해 기존의 실무 중심의 모델과 비 교를 해보면 몇 가지 큰 차이점을 발견할 수 있다. 결과물로 기존모델이 현상진단 위주이 지만 본 모델은 현상진단을 통한 향후 구체적인 전략제언이 가능하다. 측정지표간의 관계 를 보면 기존모델이 영향요인 - 결정요인 · 성과요인이 혼재되어 있으나 본 모델은 영향요인 · 결정요인 · 성과요인을 구분하여 분석이 가능하다는 점이다.

브랜드자산구성지표는 기존모델이 단일측정지표를 병렬로 구성하고 있으나 본 모델은 브 랜드성장단계에 따른 4 대 지표로 구조화하여 브랜드의 현 위치를 파악하여 척절한 전략적 대안을 수립할 수 있도록 해준다. 그리고 지표별 측정방법을 볼 때, 기존 일부모델이 지속 적이고 통일된 측정과 통제가 불가능한 방법도 있지만 (예률 들어, 버 하쿠호토 NEOHARVEST 는 주로 브랜드컨셉 개발을 위한 정성적 조사에 의존하고 있음) 본 모델은 향 후 브랜드자산의 구성지표를 높이거나 지속적으로 관리하고자 할 때 대부분 측정과 붕제 가 가능한 지표로 구성되어 있다. 


\section{4. 국내시장 적용을 위한 조사설계}

본 연구를 위해 2000 년 8 월 30 일부터 9 월 6 일에 걸쳐 국내 21 개 업종 106 개 브랜드, 두 개 업종별 300 명, 서울지역 총 3,300 명을 대상으로 표준화된 설문지에 의한 일대일 개 별면접을 실시하였다. 표본추출은 다단계 지역 확률 표집을 이용하였다 (<표2> 참조).

조사업종과 제품 품목을 선정한 기준은 업종의 대표성이 있느냐하는 점을 먼저 검토한 후 에 그 업종에서 3 개 7 개의 대표 브랜드를 선택하여 조사를 진행하였다.

<표 2> 조사업종

\begin{tabular}{|l|l|l|}
\hline 충 21 개 품목, 106 개 브랜드 \\
\hline 이동전화서비스(5) & 은행(6) & 맥주(3) \\
\hline 핸드폰(5) & 신용카드(5) & 아파트(6) \\
\hline 컴퓨터(5) & 증권(5) & 남성정장 (5) \\
\hline $\mathrm{PC}$ 통신(5) & 보험 (6) & 간장약(4) \\
\hline 초고속인터넷(5) & 중형자동차(5) & 세탁세제 (4) \\
\hline 포털사이트(5) & 휘발유(5) & 기능성화장품(5) \\
\hline 커피(7) & 우유(5) & 놀이동산(5) \\
\hline
\end{tabular}

다수의 업종과 제품 품목의 브랜드를 대상으로 동일한 브랜드자산 측정지표를 적용하여 방대한 소비자 정량조사를 실시한 것은 학계나 실무적으로 처음이라고 할 수 있으며, 소 비자조사 (CPR: Consumer Profile Research)처럼 전국적인 조사로 발전시켜 브랜드자산 지 표를 데이터베이스화할 수 있는 기반이 마련되었다고 할 수 있다.

본 연구에서는 전체 21 개 업종의 제품품목중 대표적으로 자동차업종의 “휘발유" 를 대 상으로 $\mathrm{Br}$ and Value-Up 모델의 측정지표률 세부적으로 설명하고자 한다. “휘발유” 제품 은 서울지역 26 세 54 세 남녀(비율 6:4) 총 300 명을 대상으로 한 조사결과를 바탕으로 정리되었다.

\section{5. 국내시장 업종별 분석}

\section{1 전체분석 결과}

본 연구에서는 성과지표인 Brand Performance 와 결정지표인 Awareness Power, Functional Power, Image Power 로 나누어 100 점 만점의 지수(index)를 구하여 서로의 영향관 계를 분석하였는 데, 다음과 같이 다양한 분석결과를 얻을 수 있었다 (<표 $3>$ 참조). 
우선 전체적인 분석 결과, 결정지표 중 Awareness Power 는 브랜드별로 큰 차이가 나지만, Functional Power 와 Image Power 는 브랜드별로 큰 차이를 보이지 않고 있다는 것을 알 수 있다.

Awareness Power 의 경우에는 최대값이 90.2 이고 최저값이 21.3 으로 그 차이는 68.9, 표준편차는 18.312 를 보이고 있어 분포가 넓게 나타나지만, Functional Power 는 최대값이 63.3 , 최저값이 46.5 로 그 차이가 16.8 이고 표준편차는 3.796 으로 분포가 좁게 나타나고 있으며. Image Power 또한 최대값이 64.0, 최소값이 46.0으로 그 차이가 18.0 이고 표준편 차는 4.406 으로 콘 차이를 보이지 않고 있다.

<표 3> 전체분석 결과(각 변인별 지수)

(단위 : 100 점)

\begin{tabular}{|l|l|l|l|l|l|}
\hline 변인 & 평균 & 표준편차 & 최대값 & 최소값 & 차이 \\
\hline $\mathrm{AP}$ & 51.2 & 18.312 & 90.2 & 21.3 & 68.9 \\
\hline $\mathrm{FP}$ & 53.8 & 3.796 & 63.3 & 46.5 & 16.8 \\
\hline $\mathrm{IP}$ & 54.2 & 4.406 & 64.0 & 46.0 & 18.0 \\
\hline
\end{tabular}

이러한 결과를 통해. 현재 국내 브랜드의 위상을 파악할 수 있는 데 아직까지는 세계적 인 브랜드대비 지각품질과 브랜드이미지가 강력하게 구축된 브랜드가 없으며, 국내시장에 서 브랜드의 인지도는 높아졌지만 브랜드간 제품품질과 이미지에서는 큰 차별점이 없다는 것을 알 수 있다

각 결정지표의 분석이 아닌 Brand Performance (브랜드로열티. 상대적지각가치, 구매의 향)를 종속변수로, 각 결정지표를 영향변수로 하여 회귀분석을 통한 영향요인을 분석해본 결과. Awareness Power 의 영향이 높게 나타나는 제품은 간장약. 기능섬화장품, 보험, 우 유, 세탁세제, 증권, 은행, PC 통신, 이동전화서비스이고. Functional Power 가 높게 나타 나는 것은 맥주, 커피, 남성정장이며, Image Power 가 높계 나타나는 것은 놀이동산, 신용 카드, 아파트, 중형자동차, 초고속인터넷, 컴퓨터, 포털사이트, 휘발유, 핸드폰이다.

본 연구는 톡징적으로 브랜드진화단계에 의한 브랜드자산 진단을 가능하도록 구조화되었 는데, 브랜드는 도입단계 (introduction stage), 정교화단계 (elaboration stage), 강화 단계 (fortification stage)의 시계열적 발전단계를 거진다는 점이다 (Park, Jaworski and MacInnis 1986). 이러한 브랜드진화를 가정할 때 브랜드파워는 Awareness Power $\rightarrow$ Functional Power $\rightarrow$ Image Power 로 발전한다는 개념적 틀을 상정해 볼 수 있다.

실제로 결정지표간 회거분석 결과를 보면, dwareness Power 에서 Image Power 로 영향은 낮게 나타나지만 Awareness Power $\rightarrow$ Functional Power $\rightarrow$ Image Power 로 영향은 점점 높 아지고 있는 것을 볼 수 있다 (<표 4> 참조), 세탁세제를 살펴볼 경우 Awareness Power 와 Functional Power 의 회귀분석 결과 표준화된 베타계수가 AP $\rightarrow$ FP 의 .459 (F(1, $1198)=320.1, p<.001)$ 보다 $\mathrm{FP} \rightarrow \mathrm{IP}$ 가 $.665(\mathrm{~F}(1,1198)=950.8, \propto<.001)$ 로 높게 나타났다. 전체적인 경로 분석에서 일관되개 $\mathrm{AP} \rightarrow \mathrm{FP}$ 보다 $\mathrm{FP} \rightarrow \mathrm{IP}$ 가 표준화된 베타계수가 높게 나 타나는 것을 알 수 있다. 결국, 브랜드는 인지도가 형성되고 기능적인 속성이 강화되면서 장기간에 걸쳐 관리되었을 때 비로서 강력한 이미지 파워를 갖는다고 할 수 있으며 인지도 
가 높다고 바로 강력한 이미지 파워가 형성되기는 어려운 반면 Awareness Power $\rightarrow$ Functional Power $\rightarrow$ Image Power 로의 브랜드진화를 거치면서 성장한다고 할 수 있다.

따라서, 특정 브랜드의 현재 위상을 파악하기 위해서는 Awareness Power, Functional Power, Image Power 의 평가 지수를 파악한 후에 현재 이 브랜드가 브랜드진화과정 중 어 떤 단계에 와 있는지를 판단하여 브랜드파워 중 어떤 측면을 보강해야 할지를 결정하고 그 에 따른 효과적인 마케팅전략을 수립하는 것이 가능하다.

<표 4> 회귀분석을 통해 나타낸 각 브랜드자산 구성요소들간의 관계

\begin{tabular}{|c|c|c|c|c|c|c|}
\hline 업종 & $\begin{array}{l}\mathrm{AP} \rightarrow \mathrm{FP} \\
\text { 포존화뎐벼나계숫 }\end{array}$ & $\mathrm{R}^{2}$ & $\mathrm{~F}$ 값 & 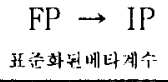 & $R^{2}$ & $\mathrm{~F}$ 값 \\
\hline 세탁세제 & .459 & .211 & $320.1 * * *$ & .665 & .687 & $950.8 * * *$ \\
\hline 우유 &. .573 & .328 & $730.7 * * *$ & .810 & .824 & $2855.0 * * *$ \\
\hline 커피 & .379 & .144 & $352.2 * * *$ & .704 & .714 & $2057.6 * * *$ \\
\hline 맥주 & .510 & .260 & $316.3 * * *$ & .753 & .787 & $1177.4 * * *$ \\
\hline 휘발유 & .523 & .273 & $563.0 * * *$ & .768 & .794 & $2156.9 * * *$ \\
\hline 간장약 & .588 & .346 & $632.4 * *$ & .770 & .797 & $1739.3 * * *$ \\
\hline 화장품 & .509 & .259 & $524.6 * * *$ & .726 & .741 & $1670.6 * * *$ \\
\hline 남성정장 & .571 & .326 & $725.8 * * *$ & .757 & .777 & $2008.2 * * *$ \\
\hline 중형자동차 & .489 & .237 & $464.7 * * *$ & .728 & .733 & $1687.5^{* * *}$ \\
\hline 아퐈트 & .459 & .211 & $480.8 * * *$ & .718 & .742 & $1912.1 * * *$ \\
\hline 핸드폰 & .504 & .254 & $510.8 * * *$ & .791 & .804 & $2511.8 * * *$ \\
\hline 컴퓨터 & .467 & .218 & $417.1 * * *$ & .766 & .782 & $2122.9 * * *$ \\
\hline 은행 & .466 & .217 & $497.9 * * *$ & .717 & .734 & $1902.0 * * *$ \\
\hline 보험 & .581 & .337 & $915.2 * * *$ & .814 & .827 & $3520.1 * * *$ \\
\hline 증권 & .518 & .268 & $547.3 * * *$ & .758 & .771 & $2028.4 * * *$ \\
\hline 신용카드 & .417 & .174 & $315.8 * * *$ & .589 & .627 & $797.2 * * *$ \\
\hline 초고속인터냇 & .347 & .121 & $205.5 * * *$ & .726 & .742 & $1669.9 * * *$ \\
\hline PC 통신 & .397 & .157 & $280.5 * * *$ & .675 & .691 & $1256.4 * * *$ \\
\hline 이동전화서비스 & .308 & .158 & $282.0 * * *$ & .711 & .751 & $1534.5 * * *$ \\
\hline 포털사이트 & .586 & .338 & $765.4 * * *$ & .771 & .795 & $2202.5 * * *$ \\
\hline 놀이동산 & $.46+$ & .215 & $411.1 * * *$ & .675 & .714 & $1255.9 * * *$ \\
\hline
\end{tabular}

$(* * * p<.001)$ 


\section{2 품목별 결과(휘발유)}

21 개 품목별 결과 중에서 대표적으로 휘발유 조사결과률 바탕으로 Brand Value-Up 모델 의 개별항목의 결과가 어떻게 나타났는지를 살펴보고 각 개별 브랜드간의 차이를 분석해 보았다.

결정지표와 성과지표간의 차이와 조사결과에 대한 전체적인 마케팅적 제언이 도출되는 과정도 다음에서 자세하게 살펴보고자 한다. 휘발유 관련 5 개의 브랜드가 Brand Value-Up 모델 조사를 위해 사용되었지만 이번 휘발유 품목 결과에서는 대표적인 3 개 브랜드 $(A, B$, $($ 브랜드)률 대상으로 비교를 실시하였다.

\subsubsection{Awareness Power}

Awareness Power 는 전체 100 점 만점에 $\mathrm{A}(83.1), \mathrm{B}(66.3), \mathrm{C}(48.0)$ 로 나타났다 $(\mathrm{F}(2$, $897)=173.9, p<.001$ ). 특히 $\mathrm{A}$ 브랜드는 다른 브랜드 대비 최초상기도 (top of mind)에서 크게 앞선 결과 전체적으로 Awareness Power 에서도 높은 점수를 보이고 있다 (<표 5> 참 조). <그림 2>에서 21 개 제품 106 개 브랜드에 대한 최초상기도 (top of mind) - 고려집합 군 포함여부 (top3)관계를 살펴보면 전체적인 추이를 살펴 볼 수 있다. $\mathrm{A}$ 브랜드 경우 둘 간 추이가 어느 정도 안정적으로 보이지만 B 나 C 브랜드 경우 현재 측정된 Top3 비울에 비 해 최초상기도가 낮은 것을 알 수 있다.

이는 $\mathrm{B}$ 브랜드의 경우 소비자들에게 잘 알려져 있기는 하지만 $\mathrm{A}$ 브랜드에 비해 최초상기 도가 낮아 선택될 가능성이 떨어진다는 것을 의미하므로 최초상기도를 더 높이기 위한 촉 진전략이 필요하다는 것올 말해준다. 한편, $\mathrm{C}$ 브랜드의 경우에는 최초상기도를 높이기 위 한 촉진전략과 함께 고려상표군에 포함되기 위한 마케팅전략도 병행되어야 할 것이다 (daker 1996, p.15)

<표 5> Awareness Power 결과

(단위: 100 점)

\begin{tabular}{|l|l|l|l|l|l|}
\hline \multicolumn{2}{|c|}{ 변인 } & \multicolumn{1}{c|}{ A } & \multicolumn{1}{c|}{ B } & \multicolumn{1}{c|}{ C } & \multicolumn{1}{c|}{ F 값 } \\
\hline \multirow{4}{*}{ Awar eness Power } & 평균 & 83.1 & 66.3 & 48.0 & 173.9 \\
\cline { 2 - 7 } & 표준편 차 & 21.24 & 24.43 & 23.43 & $* * *$ \\
\cline { 2 - 7 } & Duncan & a & b & c & \\
\hline Top of Mind & & 53.3 & 18.7 & 6.3 & - \\
Top3 & & 85.3 & 72.3 & 47.7 & - \\
Unaided Recall & & 86.7 & 76.7 & 67.3 & - \\
Aided Recall & & 100.0 & 100.0 & 99.3 & - \\
\hline (***p.001) & & \multicolumn{3}{|c}{} \\
\hline
\end{tabular}


<그림 2> 최초상기도(TOM)-고려집합군 포함여부(Top3) 관계

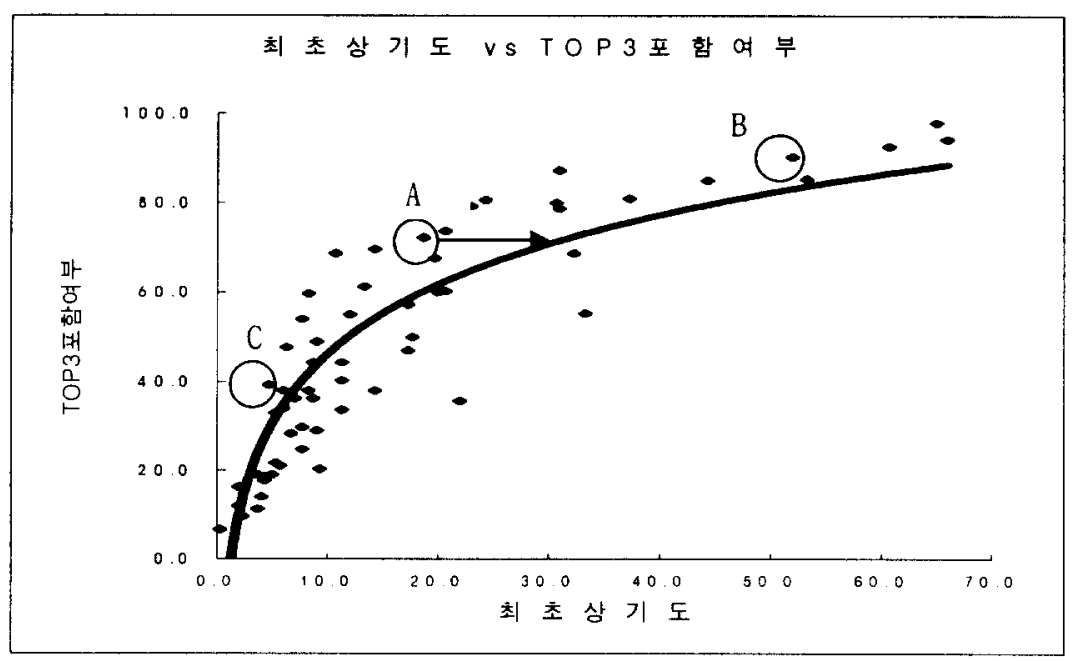

\subsubsection{Functional Power}

Functional Power 는 공해적음, 연비우수, 엔진보호기능, 깨끗함, 옥탄가 높음, 힘이 좋 음, 찌꺼기 없음, 가격저렴, 정유사보너스카드, 직원서비스, 제휴신용카드, 부대시설 등의 항목을 사용하였다. 제일기힉 기존 조사 자료에서 사용된 신뢰성 높은 항목을 추출하여 항 목을 선정하였다 (<표 6> 참조). Functional Power 를 측정하기 위한 12 개의 속성항목에 대한 신뢰도분석에서는 크론바하 $\alpha$ 가 .8809 로 매우 높게 나타났다. 각 브랜드에 대한 Functional Power 는 100 점 만점에 $\mathrm{A}(60.5), \mathrm{B}(57.1), \mathrm{C}(51.6)$ 으로 각각 나타났다 ( $\mathrm{F}(2$, $897)=148.8, p<.001)$. 브랜드간 평균 차이에 대한 다중비교를 위해 Duncan 분석을 실시한 결과, “연비가 우수하다” “옥탄가가 높다" 라는 항목을 제외하곤 각 브랜드간 평균에 대 한 차이가 있다고 할 수 있다.

이런 결과를 바탕으로 <그림 $3>$ 과 같이 속성지각도를 통한 전략적 대안을 도출할 수 있 다. 중요도와 속성평가 (강도)간 관계에서 중요도와 속성평가가 높은 속성으로 공해적음, 찌꺼기없음, 깨끗함이 해당되며, 중요도는 높지만 속성평가는 낮은 속성으로 보너스카드와 제휴신용카드가 해당된다. 따라서 Functional Power 에서 기본적으로는 공해와 찌꺼기 둥 을 줄이는데 노력해야겠지만 현재 정유사업체간 경쟁적으로 실시하는 보너스카드는 과거 보다는 그 차별성과 중요성이 떨어지고 있어 이에 대한 개선이 필요하다는 것을 알 수 있 다. 
<표 6> Functional Power 결과

(단위: 100 점)

\begin{tabular}{|c|c|c|c|c|c|}
\hline \multicolumn{2}{|l|}{ 변인 } & $A$ & B & $\mathrm{C}$ & $\mathrm{F}$ 값 \\
\hline \multirow{3}{*}{ Functional Power } & 평균 & 60.5 & 57.1 & 51.6 & 148.8 \\
\hline & 표준편차 & 6.67 & 5.95 & 6.42 & $* * *$ \\
\hline & Duncan & a & $\mathrm{b}$ & c & \\
\hline \multirow{3}{*}{ [01] 공해가 적다 } & 평 간 & 5.34 & 5.11 & 4.63 & 48.4 \\
\hline & 포준펵차 & 0.88 & 0.87 & 0.94 & $* * *$ \\
\hline & Duncan & a & $b$ & c & \\
\hline \multirow{3}{*}{ [02] 연비가 우수하다 } & 涶균 & 5.28 & 5.15 & 4.55 & 56.0 \\
\hline & 표준편차 & 0.93 & 0.92 & 0.86 & $* * *$ \\
\hline & Duncan & a & a & c & \\
\hline \multirow{3}{*}{ [03] 엔진보호 기능이 있다 } & 평 균 & 5.29 & 5.04 & 4.49 & 55.0 \\
\hline & 표준편차 & 0.99 & 0.89 & 0.99 & $* * *$ \\
\hline & Duncan & a & b & $\mathrm{c}$ & \\
\hline \multirow{3}{*}{ [04] 깨끗하다 } & 평균 & 5.27 & 4.94 & 4.48 & 48.1 \\
\hline & 표준편차 & 1.03 & 0.93 & 1.01 & $* * *$ \\
\hline & Duncan & a & $b$ & c & \\
\hline \multirow{3}{*}{ [05] 옥탄가가 높다 } & 평균 & 5.08 & 4.94 & 4.55 & 22.0 \\
\hline & 표준편차 & 0.97 & 1.07 & 1.01 & $* * *$ \\
\hline & Duncan & a & a & b & \\
\hline \multirow{3}{*}{ [06] 힘이 좋다 } & 평 균 & 5.19 & 5.00 & 4.56 & 30.5 \\
\hline & 표준편차 & 1.01 & 1.00 & 1.03 & $* * *$ \\
\hline & Duncan & a & $\mathrm{b}$ & c & \\
\hline \multirow{3}{*}{ [07] 찌꺼기가 없다 } & 평균 & 5.34 & 4.90 & 4.51 & 60.7 \\
\hline & 표준편차 & 0.95 & 0.89 & 0.95 & $* * *$ \\
\hline & Duncan & $\mathrm{a}$ & $\mathrm{b}$ & c & \\
\hline \multirow{3}{*}{ [08] 가격이 저렴하다 } & 평균 & 4.62 & 4.41 & 4.50 & 2.4 \\
\hline & 표준편차 & 1.23 & 1.21 & 1.14 & \\
\hline & Duncan & a & $b$ & $\mathrm{c}$ & \\
\hline \multirow{3}{*}{$\begin{array}{l}\text { [09] 정유사 보너스 카드가 } \\
\text { 잘 되어 있다 }\end{array}$} & 평균 & 5.47 & 5.05 & 4.38 & 87.5 \\
\hline & 포준편 차 & 1.03 & 1.01 & 1.01 & $* * *$ \\
\hline & Duncan & a & b & c & \\
\hline \multirow{3}{*}{ [10] 주유소내 직원의 서비스가 줗다 } & 평균 & 5.27 & 5.03 & 4.60 & 34.8 \\
\hline & 正준편차 & 0.94 & 0.97 & 1.06 & $* * *$ \\
\hline & Duncan & a & $b$ & c & \\
\hline
\end{tabular}




\begin{tabular}{|c|c|c|c|c|c|}
\hline \multirow{3}{*}{$\begin{array}{l}\text { [11] 정유사 제휴신용카드가 } \\
\text { 잘 되어 있다 }\end{array}$} & 평균 & 5.44 & 5.03 & 4.47 & 68.9 \\
\hline & 표준편차 & 1.00 & 1.01 & 1.03 & $* * *$ \\
\hline & Duncan & $\mathrm{a}$ & b & $\mathrm{c}$ & \\
\hline \multirow{3}{*}{ [12] 주유소 부대시설이 좋다 } & 평균 & 5.15 & 4.89 & 4.54 & 30.5 \\
\hline & 표준편차 & 0.95 & 0.97 & 0.98 & $* * *$ \\
\hline & Duncan & a & $b$ & c & \\
\hline \multicolumn{2}{|l|}{ Cronbach 알파 } & \multicolumn{4}{|c|}{0.8809} \\
\hline
\end{tabular}

<그림 3>A브랜드 속성지각도

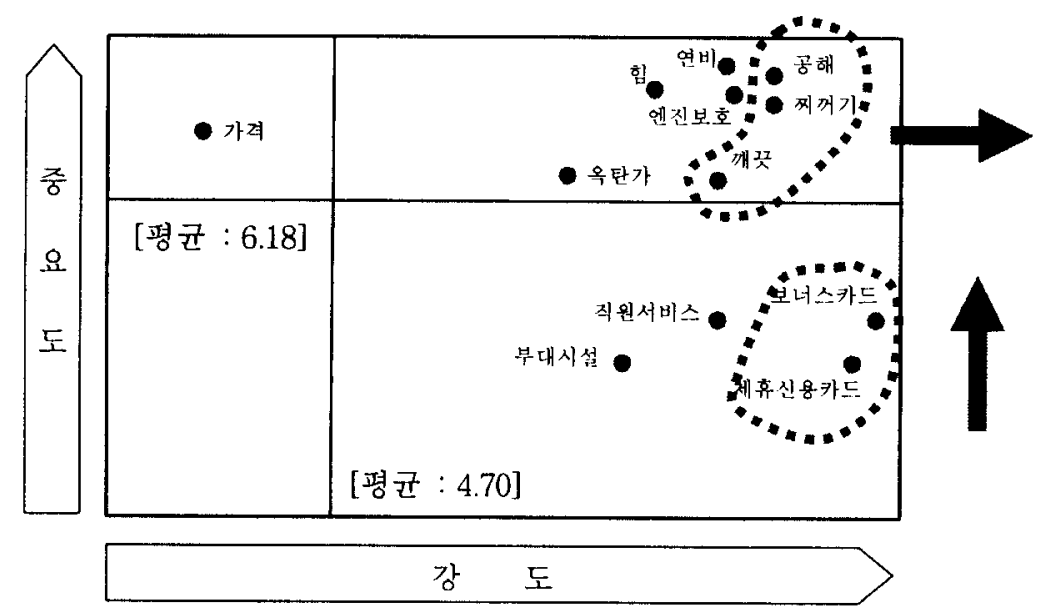

\subsubsection{Image Power}

Image Power 는 브랜드-개인간의 관계를 살펴보는(Intra Personal Fit) Personal Image Power 와 브랜드-주변간의 관계를 살펴보는(Inter Personal Fit) Social Image Power 로 구 분된다.

Personal Image Power 는 요인분석을 통해 현재 한국사람의 개성을 표현하는 이미지를 106 개로 추출하고 다시 상대적으로 표현되는 형용사 (예를 들어 남성적인-여성적인 등)를 제외한 홍 76 개의 대표적인 이미지 (형용사)를 선택하였다. 그리고 최종적으로 해당 업종 에 해당되는 형용사 26 개를 선택하여 측정하였다. 26 개 모든 형용사에 대한 중요성 비중 을 찾아내고 응답자의 부담을 덜어주기 위해 우선 26 개 중 “자신의 추구이미지" 로 5 개를 먼저 선택하게 한 후 각 브랜드에 대한 관계 (Fit)를 평가하도록 하였다.

전체적으로 휘발유 브랜드에서 브랜드-개인간의 이미지충족도는 활동적인 $(45.0 \%)$, 전문 적인 $(42.3 \%)$, 믿음직한 $(41.7 \%)$, 자신감있는 $(34.0 \%)$, 개성있는(31.7\%), 친절한 $(25.7 \%)$, 건 전한 (26.3\%) 등의 순으로 조사되었다. 그리고 Personal Image Power 는 100 점 만점에 브 랜드별 평가는 $\mathrm{A}(61.6), \mathrm{B}(58.6), \mathrm{C}(50.7)$ 로 나타났다 $(\mathrm{F}(2,897)=167.1, p \times .001)$. 대체적 
으로 A 브랜드가 높은 평가를 보이지만, "개성있는" 항목에서는 B 브랜드(4.95)가 A 브랜드 (4.94)를 앞서는 것으로 나타났다. 다중 비교를 위한 Duncan 분석에서는 Functional Power 와 달리 $\mathrm{A}$ 브랜드와 $\mathrm{B}$ 브랜드간에 차이가 없는 것으로 나타넜다 (믿음직한, 자신감있는, 개 성있는, 친절한, 건전한, 현실적인, 자유로운). 이 결과를 통해 $\mathrm{A}$ 브랜드와 $\mathrm{B}$ 브랜드의 평 균이 통계적으로 유의미할 정도로 차이가 나지 않는다는 것을 알 수 있으며 두 브랜드간 Personal Image Power 의 이미지의 차이는 크지 않다고 할 수 있다 (<표 7> 참조).

<표 7> Personal Image Power 결과

\begin{tabular}{|c|c|c|c|c|c|}
\hline \multicolumn{2}{|c|}{ 변인 } & $d$ & B & C & $\mathrm{F}$ 값 \\
\hline \multirow{3}{*}{ Persona! Image Power } & 평균 & 61.6 & 58.6 & 50.7 & 167.1 \\
\hline & 표준편차 & 7.92 & 7.36 & 7.21 & $* * *$ \\
\hline & Duncan & a & $b$ & c & \\
\hline \multirow{3}{*}{ [01] 활동적인 } & 평균 & 5.58 & 5.22 & 4.42 & 54.8 \\
\hline & 표준편차 & 0.91 & 0.94 & 0.94 & $* * *$ \\
\hline & Duncan & a & b & c & \\
\hline \multirow{3}{*}{ [02] 전문적인 } & 평균 & 5.59 & 5.35 & 4.53 & 40.3 \\
\hline & 표준편차 & 0.89 & 1.06 & 1.01 & $* * *$ \\
\hline & Duncan & $\mathrm{a}$ & b & c & \\
\hline \multirow{3}{*}{ [03] 믿음직한 } & 평균 & 5.34 & 5.20 & 4.56 & 27.1 \\
\hline & 표준편차 & 0.96 & 0.87 & 0.84 & $* * *$ \\
\hline & Duncan & a & a & b & \\
\hline \multirow{3}{*}{ [04] 자신감있는 } & 평균 & 5.46 & 5.32 & 4.61 & 29.5 \\
\hline & 표준편차 & 0.77 & 0.82 & 0.96 & $* * *$ \\
\hline & Duncan & a & a & b & \\
\hline \multirow{3}{*}{ [05] 개성있는 } & 평간 & 4.94 & 4.95 & 4.28 & 11.7 \\
\hline & 표준편차 & 1.10 & 1.06 & 1.09 & $* * *$ \\
\hline & Duncan & $\mathrm{a}$ & à & b & \\
\hline \multirow{3}{*}{ [06] 친절한 } & 평균 & 5.53 & 5.31 & 4.69 & 16.0 \\
\hline & 표준편차 & 1.03 & 0.86 & 0.98 & $* * *$ \\
\hline & Duncan & a & a & b & \\
\hline \multirow{3}{*}{ [07] 건전한 } & 평 균 & 5.41 & 5.13 & 4.66 & 11.3 \\
\hline & 표준편차 & 0.94 & 0.92 & 1.12 & $* * *$ \\
\hline & Duncan & a & $a$ & $\mathrm{~b}$ & \\
\hline
\end{tabular}




\begin{tabular}{|c|c|c|c|c|c|}
\hline \multirow{3}{*}{ [08] 세련된 } & 평균 & 5.30 & 4.89 & 4.21 & 24.0 \\
\hline & 표준편차 & 0.90 & 1.02 & 1.14 & $* * *$ \\
\hline & Duncan & $\mathrm{a}$ & b & c & \\
\hline \multirow{3}{*}{ [09] 현실적인 } & 평균 & 5.11 & 4.99 & 4.56 & 4.5 \\
\hline & 표준편차 & 1.30 & 1.12 & 1.02 & * \\
\hline & Duncan & a & $\mathrm{a}$ & b & \\
\hline \multirow{3}{*}{ [10] 자유로운 } & 평균 & 5.41 & 5.06 & 4.31 & 18.5 \\
\hline & 표준편차 & 0.97 & 1.02 & 1.13 & $* * *$ \\
\hline & Duncan & $\mathrm{a}$ & $\mathrm{a}$ & $\mathrm{b}$ & \\
\hline \multirow{3}{*}{ [11] 감성적인 } & 평균 & 5.27 & 4.32 & 4.55 & 5.3 \\
\hline & 표준편차 & 0.88 & 0.95 & 1.18 & $* *$ \\
\hline & Duncan & $a$ & $b$ & $b$ & \\
\hline
\end{tabular}

$(* p<.05, * * p<.01, * * * p<.001)$

Social Image Power 는 주위수용, 주위선호, 선망하는 대상 사용가능성, 관심/화제성, 인기예상, 시대적분위기/추세로 측정하였다. 각 브랜드의 평가는 $\mathrm{A}(61.8), \mathrm{B}(58.7), \mathrm{C}$ $(50.7)$ 로 나타났다 $(\mathrm{F}(2,897)=200.7, p<.001)$. Social Image Power 를 측정하는 6 개의 항 목에 대한 신뢰도 분석에서는 크론바하 $\boldsymbol{\alpha}$ 가 .9142 로 매우 높게 나타났다. 또한 Duncan 분 석에서도 각 브랜드간 평균차이가 모든 항목에서 유의미한 것으로 나타났다 (<표 8> 참조). Social Image Power 에서는 주위수용에서 A 브랜드는 평균(5.57)이 다른 브랜드에 비해 높 게 나타났을 뿐만 아니라 $(\mathrm{F}(2,897)=103.3, p \times .001)$, 주위선호 둥 항목에 비해서도 높게 평가 되었다. 휘발유 브랜드에서 $\mathrm{A}$ 브랬드는 다른 브랜드에 비해 높은 점수를 받게 되었는 데 그만큼 사회적으로 평가되는 이미지에서 앞선 경쟁력을 가지고 있다고 볼 수 있다.

Personal Image Power 에서는 큰 차이를 보이고 있지 않은 A 와 B 브랜드는 Social Image Power 에서는 그와는 반대로 모든 항목에서 큰 차이를 보이고 있다. B 브랜드는 그만큼 Personal Image Power 에서는 이미지간 차별성을 갖지 못하고 비슷하게 나타나고 있기 때 문에 Social Image Power 를 높이기 위한 브랜드전략을 고려할 수 있을 것이다. 이와 같이 Image Power 를 개인적 차원과 사회적 차원으로 나누어 분석할 경우 향후 어떤 이미지를 보완 발전시켜야 하는지 보다 세분화된 분석을 가능하게 한다.

<표 8> Social Image Power 결과

(단위 : 100 점)

\begin{tabular}{|l|l|l|l|l|l|}
\hline \multicolumn{2}{|c|}{ 변인 } & \multicolumn{1}{c|}{ d } & \multicolumn{1}{c|}{ B } & \multicolumn{1}{c|}{ C } & \multicolumn{1}{|c|}{ F 값 } \\
\hline \multirow{3}{*}{ Social Image Power } & 평 균 & 61.8 & 58.7 & 50.7 & 200.7 \\
\cline { 2 - 7 } & 표준편차 & 7.27 & 7.23 & 6.87 & $* * *$ \\
\cline { 2 - 7 } & Duncan & a & b & c & \\
\hline
\end{tabular}




\begin{tabular}{|c|c|c|c|c|c|}
\hline \multirow{3}{*}{ [01] 주위수용 } & 평 균 & 5.57 & 5.18 & 4.53 & 103.3 \\
\hline & 표준편차 & 0.82 & 0.95 & 0.92 & $* * *$ \\
\hline & Duncan & a & $b$ & c & \\
\hline \multirow{3}{*}{ [02] 주위선호 } & 평 균 & 5.50 & 5.14 & 4.47 & 89.0 \\
\hline & 표준편차 & 0.99 & 0.93 & 0.96 & $* * *$ \\
\hline & Duncan & a & $b$ & c & \\
\hline \multirow{3}{*}{ [03] 선망하는 대상 사용가능섬 } & 평균 & 5.14 & 4.96 & 4.40 & 44.9 \\
\hline & 표준편차 & 0.93 & 1.05 & 1.04 & $* * *$ \\
\hline & Duncan & a & $b$ & c & \\
\hline \multirow{3}{*}{ [04] 관심/화제성 } & 평규 & 5.18 & 5.05 & 4.33 & 63.3 \\
\hline & 포준편차 & 1.02 & 0.99 & 0.97 & $* * *$ \\
\hline & Duncan & a & a & $b$ & \\
\hline \multirow{3}{*}{ [05] 인기예상 } & 평균 & 5.23 & 5.01 & 4.37 & 56.4 \\
\hline & 표준편차 & 1.03 & 1.09 & 0.97 & $* * *$ \\
\hline & Duncan & a & b & c & \\
\hline \multirow{3}{*}{ [06] 시대적 분위기/추세 } & 평 균 & 5.25 & 5.05 & 4.38 & 62.9 \\
\hline & 표준편차 & 0.95 & 1.03 & 0.99 & $* * *$ \\
\hline & Duncan & a & $b$ & c & \\
\hline \multicolumn{2}{|l|}{ Cronbach 알파 } & \multicolumn{4}{|l|}{0.9142} \\
\hline
\end{tabular}

$(* * * p<.001)$

\subsubsection{Brand Performance}

전체적인 $\mathrm{Br}$ and Performance 결과는 $\mathrm{A}(75.3), \mathrm{B}(62.3), \mathrm{C}(47.6)$ 으로 브랜드간 큰 차이를 보이고 있다 $(\mathrm{F}(2,897)=208.0, \not \times .001)$. 특히, 브랜드로열티에서 가장 콘 차이를 보이고 있으며 $(\mathrm{F}(2,897)=111.6, p \times .001)$. 상대적 지각가치와 구매의향에서도 $\mathrm{A}, \mathrm{B}, \mathrm{C}$ 브랜드간 차이가 나타나는 것으로 조사되었다. 상대적지각가치는 $\mathrm{A}(93.8)$ 가 매우 높은 수치를 보이 고 있는데 그만큼 다른 브랜드와 비교하여 평가하는 경우에 높게 평가되고 있다는 것을 알 수 있다. 구매의향울 측정한 경우에는 상대적으로 $\mathrm{C}(59.4)$ 가 경쟁우위에 있는 브랜드(A. $\mathrm{B}$ )에 비해 더 낮게 평가되는 것으로 알 수 있다 $(\mathrm{F}(2,897)=173.1, p<.001)$ (<표 9> 참조). $\mathrm{Br}$ and Value-Up 모델은 톡히 브랜드성과를 측정하기 위해 행동적인 지표로서의 브랜드로 열티, 경쟁 브랜드를 고려한 상대적인 지각가치, 구매의향으로 세분화하여 조사하고 있는 데 브랜드 성과를 구매행동과 경쟁상황에 대한 인식을 고려하여 종합적으로 측정하고 있어 개별적인 브랜드성과 뿐만 아니라 전체적인 성과를 측정하기에 적합하다. 특히 브랜드 로. 열티는 [이전-현재-미래]에 선택하는 브랜드를 조사하기 때문에 좀더 실제 행동적인 측면 에서 각 브랜드 경쟁력을 살펴볼 수 있다. 
<표 9> Brand Performance Index 결과

\begin{tabular}{|c|c|c|c|c|c|}
\hline \multicolumn{2}{|l|}{ 변인 } & A & B & C & $\mathrm{F}$ 값 \\
\hline \multirow{3}{*}{ Brand Performance Index } & 평균 & 75.3 & 62.3 & 47.6 & 208.0 \\
\hline & 표준편차 & 19.91 & 17.96 & 14.99 & $* * *$ \\
\hline & Duncan & a & $b$ & c & \\
\hline \multirow{3}{*}{ Brand Loyalty } & 평균 & 49.1 & 20.9 & 7.7 & 111.6 \\
\hline & 표준편차 & 43.90 & 34.72 & 21.80 & $* * *$ \\
\hline & Duncan & a & $b$ & c & \\
\hline \multirow{3}{*}{ Relative Perceived Value } & 평균 & 93.8 & 89.3 & 75.5 & 176.5 \\
\hline & 표준편차 & 9.73 & 11.24 & 15.48 & $* * *$ \\
\hline & Duncan & a & b & c & \\
\hline \multirow{3}{*}{ Purchase Intent ion } & 평균 & 83.0 & 76.7 & 59.4 & 173.1 \\
\hline & 표준편차 & 14.03 & 16.75 & 17.29 & $* * *$ \\
\hline & Duncan & a & b & c & \\
\hline
\end{tabular}

\section{5. 결론}

브랜드에 대한 최근의 관심은 학계와 실무분야 모두에서 급속히 증가하고 있다. 이에 따 라 기업의 인수, 합병 둥을 둘러싸고 한 브랜드의 가치를 어뗳게 측정할 것인가에 대한 연 구가 꾸준히 이루어지고 있으며, 이와 함께 보다 가치있는 브랜드를 만들어 내고 이를 지 속적으로 관리 및 강화시켜 나가기 위한 브랜드 자산의 진단 및 관리모델 개발에 대한 필 요성이 대두되어 왔다. 본 연구는 브랜드 자산의 진단 및 관리를 위해 만들어진 기존의 여 러 브랜드 모델들을 검토하고 이들이 갖는 잠재적 문제점들과 개념적인 타당성 및 실무적 유용성을 고려하여 보다 의미있는 하나의 브랜드 관리모델을 제시함을 목표로 하고 있다.

제시된 모델의 몇 가지 특징을 살펴보면, 우선 본 연구에서는 기존에 연구된 그리고 실 제적으로 중요한 브랜드 자산과 관련된 여러 변수들을 빠짐없이 파악하여 이들 변수들올 개념적 타당성과 전략적 유용성을 기준으로 인지적 요인, 기능적 요인, 개인적 이미지 요 인, 사회적 이미지 요인, 그리고 브랩드 성과 변수의 5 개 범주로 분류하였다. 결과적으로 주로 인지도나 연상적인 측면에 편중된 기존의 모델보다 충실하고 포팔적인 내용을 갖게 됨과 동시에 기업의 전략 수립이라는 측면에서도 의미있는 모델이라고 판단된다. 다음으로, 기존 모델들의 가장 큰 문제점으로 지적된 브랜드 자산의 구성 및 측정변수들 간의 인과관 계가 반영되지 않은 평면적 모델구조를 개선하였다는 것이다. 예를 들어, 과거 브랜드 성 과에 대한 독립변수로 다루어져 온 브랜드 충성도는 과연 브랜드 자산의 원인변수인가? 브 랬드 충성도는 브랜드 자산 자체의 한 측정변수로 보는 것이 보다 적절한 이해일 것이다. 본 연구에서는 위에서 제시된 5 개 범주의 변수들 간의 가능한 인과관계를 고려하여 보다 
개념적으로 타당한 입체적인 구조의 모델을 제시합과 동시에 이를 실증적으로도 검중하고 자 했다. 이에 따라 기업의 브랜드 성과에 문제가 발생하거나 이를 강화시키고자 할 때 브 랜드의 어느 측면에 우선적인 노력이 기울여져야 하는지에 대한 지침을 제공할 수 있게 되 었다. 본 모델의 또 다른 특징으로는, 시장과 브랜드가 수명주기선 상에서 전개됨에 따라 브랜드 자산에 영향을 주는 요인들 간의 전략적 초점이 어떤 식으로 진화해 나가는지에 대 한 브랜드 진화론적인 분석 역시 시도되었다는 점이다. 일반적인 진화패턴은 예상대로 인 지도 $\rightarrow$ 기능적 품질지각 $\rightarrow$ 이미지적인 적합도 지각이라는 일련의 과정을 통해서 브랜드 는 성장하고 진화되어 나감을 알 수 있었다.

본 연구에서 제시된 모델은 다음과 같은 방향으로 더욱 보완되어져야 할 것이다. 먼저 이 모델이 보다 전략적으로 의미있는 모델이 되기 위해서는 제시된 브랜드 성과에의 영향 요인들이 기업의 일련의 구체적인 마케팅 전략활동들(예: 광고, 유통, 가격 둥)과 연계되 어 모델 상에서 파악된 진단사항들이 기업의 세부 전략으로 직접적으로 연결될 수 있을 경 우 보다 유용한 모델이 될 수 있을 것이다. 다음으로 변수들의 측정방법 상의 문제가 좀 더 보안될 필요가 있다. 예를 들어. 국내 여러 브랜드들을 대상으로 모델을 적용시켜 본 결과 브랜드 간의 제품력이나 톡히 이미지 면에서의 차이가 인지도 상에서의 차이에 비해 뚜렷이 떨어지는 현상을 볼 수 있는데 이는 실제 현상을 반영했을 가능성도 있으나, 척도 상의 한계에 따른 결과일 가능성 역시 배제할 수 없다. 끝으로, 모델의 여러 산업에의 적 용결과 그 적합도가 산업별로 상당한 차이를 보이는 것이 나타났다. 따라서 브랜드 성과에 영향을 줄 수 있는 산업별, 시장별 상항변수들도 모델에 반영된 보다 정교한 모델의 구축 이 필요할 것이다. 


\section{<참고문헌>}

안광호, 한상만, 전성를 (2003), 전략적브랜드관리, 서울, 학현사.

이학식, 안광호, 하영원 (2001), 소비자행동, 서울, 법문사.

산업정책연구원 IPS2003 브랜드가치평가 발표 및 브랜드가치 제고 전략세미나.

Aaker, David A. (1991), Managing Brand Equity: Capitalizing on the Value of a Brand

Name. New York: Free Press.

(1996), Building Strong Brands. New York: Free Press.

Aaker, Jennifer (1997), "Dimensions of Brand Personality," Journal of Marketing Research, 34 (August), 347-357.

Ajen, Icek and Mart in Fishbein (1980), Understanding Attitudes and Predicting Social

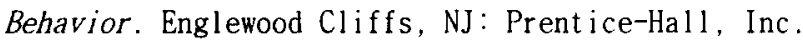

Axelrod, Joel N. (1968), “Attitude Measures That Predict Purchase," Journal of Advertising Research, 8 (1), 3-17.

(1986), “Minnie, Minnie Tickled the Parson," Journal of Advertising Research, 26 (1), 89-96.

Farquhar, Peter H. (1989), "Managing Brand Equity," Marketing Research, 1 (September), 74-75.

Fishbein, Martin, and Icek Ajzen (1975), Belief, Attitude, Intention and Behavior: An Introduction to Theory and Research. Reading, MA: Addison-Wesley.

Fournier, Susan (1998), "Consumers and Their Brands: Developing Relationship Theory in Consumer Research," Journal of Consumer Research, 24 (March), 343-373.

Hutchinson, J. Wesley, Kalyan Raman and Murali K. Mantrala (1994), "Finding Choice Alternatives in Memory: Probability Models of Brand Name Recall," Journal of Marketing Research, 31 (November), 441-461.

Interbrand (2003), "The World's Most Valuable Brands 2003," Interbrand's Annual Survey.

Jacoby, Jacob and Robert W. Chestnut (1978), Brand Loyalty: Measurement and Management, Chichester and New York: Wiley.

Kahn, Barbara E., Manohar Kalwani, and Donald G. Morrison (1988), "Niching Versus Change-of-Pace Brands: Using Purchase Frequencies and Penetration Rates to Infer Brand Positionings," Journal of Narketing Research, 25 (November), 384-90.

Kamakura, Wagner A. and Gary J. Russell (1989), "Measuring Brand Value With Scanner Data," International Journal of Research in Marketing, 10 (March), 9-22.

Keller, Kevin L. (1993), "Conceptualizing, Measuring, and Managing Customer-Based Brand Equity," Journal of Marketing, 57 (January), 1-22.

(1998), Strategic Brand Management: Building, Measuring, and Managing Brand Equity, Upper Saddle River, New Jersey: Prentice-Hall, Inc.

Kotler, Philip H. (2003), Marketing Management, the 1lth ed. Englewood Cliffs, NJ: Prent ice-Hall, Inc.

Machleit, Karen A, and R. Dale Wilson (1988), "Emotional Feelings and Attitudes 
toward Advertisement: The Roles of Brand Familiarity and Repetition," Journal of Advertising, 17 (3), 27-35.

Mackenzie, Scot. B., Richard J. Lutz, and George E. Belch (1986), "The Role of Attitude Toward the Ad as a Mediator of Advertising Effectiveness: A Test of Compet ing Explanations," Journal of Marketing Research, 23 (May), 130-143.

Miller, Stephen and Lisette Berry (1998), "Brand Salience versus Brand Image: Two Theories of Advertising Effectiveness." Journal of Advertising Research, 38 (5), 77-82.

Nedungadi, Prakash (1990), "Recall and Consumer Consideration Sets: Influencing Choice without Altering Brand Evaluations," Journal of Consumer Research, 17 (December), 263-276.

Nicosia, Francesco and Robert N. Mayer (1976), "Toward a Sociology of Consumpt ion," Journal of Consumer Research, 3 (September), 65-75.

Papatla, Purushottam and Lakshman Krishnamurthi (1996), "Measuring the Dynamic Effects of Promotions on Brand Choice," Journal of Marketing Research, 28 (February), 20-35.

Park, C. Whan, Bernard J. Jaworski, and Deborah J. MacInnis (1986), "Strategic Brand Concept-Image Management," Journal of Jarketing, 50 (October), 135-145.

Park, Chan Su and V. Srinivasan (1994), "A Survey-Based Method for Measuring and lnderstanding Brand Equity and Its Extendibility," Journal of Marketing Research. 68 (May). 271-288.

Plummer, Joseph T. (1985), "How Personality Makes a Difference," Journal of Advertising Research, 24 (6), 27-31.

Simon, Carol J. and Mary W. Sullivan (1993), "The Measurement and Determinants of Brand Equity: A Financial Approach," Narketing Science, 12 (Winter), 28-52.

Solomon. Michael R. (1983), "The Role of Products as Social Stimuli: A Symbolic Interactionism Perspective," Journal of Consumer Research, 10 (December), 319329.

van Osselaer. Stijn M. J. and Joseph W. Alba (2000), "Consumer Learning and Brand Equity," Journal of Consumer Research, 27 (June), 1-16.

van Osselaer, Stijn M. J. and Chris Janiszewski (2001), "Two Ways of Learning Brand Associations," Journal of Consumer Research, 28 (September), 202-223.

Zeithaml, Valarie A. (1988), "Consumer Perceptions of Price. Quality, and Value: A Means-End Model and Synthesis of the Evidence," Journal of Marketing, 52 (July), 2-22. 